\title{
Hydrogen cars fuel debate on basic research
}

Geoff Brumfiel, Washington

Experts are questioning the lack of university involvement in President Bush's initiative to produce a competitive hydrogen-fuelled car by 2020 .

The programme was launched early last year and was augmented in January when Bush announced a \$1.7-billion, five-year research initiative to develop the technology and infrastructure to meet the project's goals.

When both houses of Congress held hearings last week to review the programme, no academic scientist was invited. Instead, committees in the House and the Senate asked technical managers of companies such as Shell and General Motors, together with environmental and industrial lobbyists, to testify.

But experts say that the programme dubbed FreedomCAR (Cooperative Automotive Research) — needs a strong basicresearch component if it is to come close to its ambitious goals. "Universities should have a much, much larger role in FreedomCAR," says Daniel Sperling, director of the Institute of Transportation Studies at the University of California, Davis.

FreedomCAR focuses on industrial research and development, as did the Partnership for a New Generation of Vehicles (PNGV) set up under Bill Clinton's administration, which it replaces (see Nature 415,

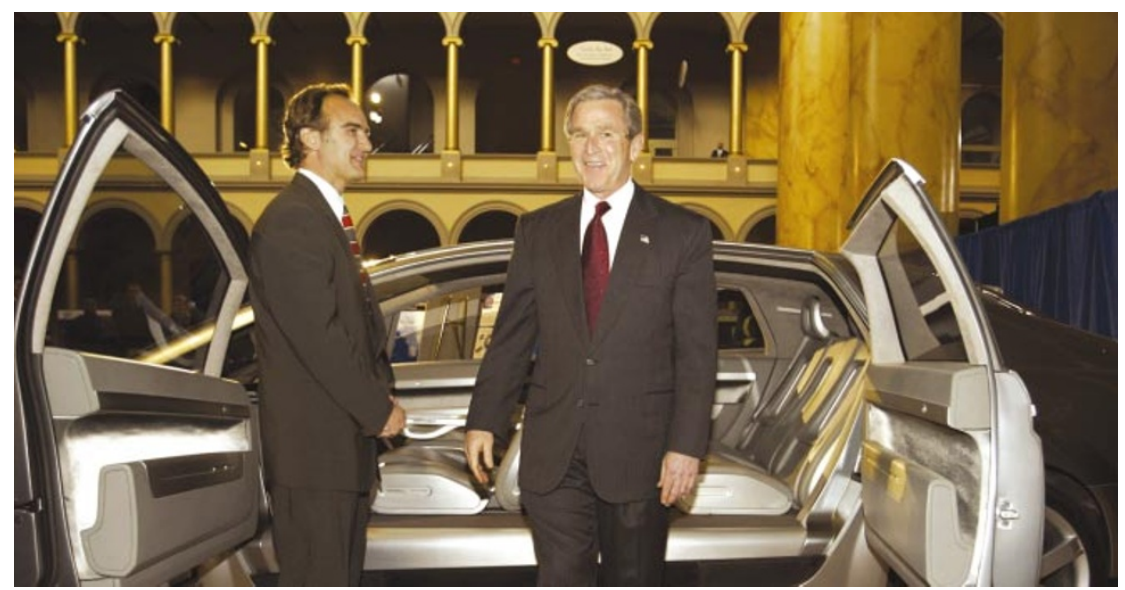

On the road: President Bush wants to see hydrogen-powered cars become a commercial reality.

248; 2002). But unlike the PNGV, which sought to increase the efficiency of existing technologies and components, the Bush programme will require an entirely new set of hydrogen-based technologies.

It aims to develop vehicles that will run on battery-like hydrogen fuel cells. Another component of the programme, the Hydrogen Fuel Initiative, would develop the infrastructure to transport and sell hydrogen fuel for the cars.

"The basic science underlying hydrogen fuel cells is very weak," says Sperling. Major

\section{Russia pulls out of Antarctic station}

\section{Bryon MacWilliams, Moscow}

The 13 crew members expected to arrive this week at Russia's Mirny Observatory on the Antarctic coast are likely to be tired and cold, and with good reason. When the

Vostok research base at which they work ran out of fuel and supplies last month, the team was forced to take their Soviet-era trucks on a 1,400-kilometre journey across one of the coldest regions on Earth.

Vostok, which is near to the south geomagnetic pole, was abandoned for the winter on 28 February after bad weather prevented a convoy carrying fuel and supplies from reaching it. Valery Lukin of the Arctic and Antarctic Research Institute in St Petersburg, says that trips to the base have been disrupted since a supply ship attempting to reach Mirny became trapped in ice last year.

The crew's convoy was briefly stranded on 5 March when one of the trucks broke down, but it is expected to arrive at Mirny by 15 March. The same personnel are scheduled to reopen the base in early November, at the start of Antarctica's spring.
Lukin says that a proposed international project to drill into Lake Vostok, $4 \mathrm{~km}$ beneath the ice (see Nature 415, 828-830; 2002) will not be affected. Biologists suspect that the lake, which been isolated for millions of years, could contain life.

The base has shut three times before in its 45-year history, although two of those closures were in the past decade. Lukin denies suggestions that a lack of government money is to blame. "This in no way means that Russia can't financially support its base," he says. "It is related to the climatic conditions."

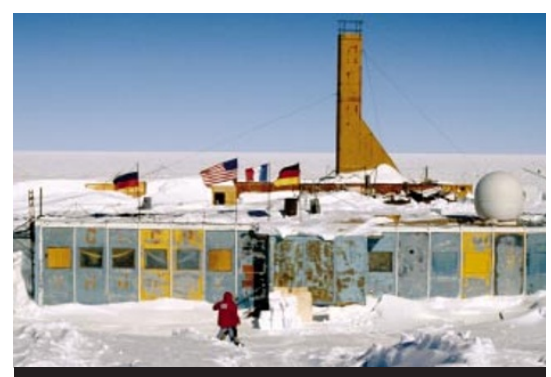

Russia's Vostok station is closed for the winter. problems still dog the efficiency and reliability of the cells, and their integration into vehicle design. Over a dozen US universities have active fuel-cell research programmes.

"Universities need to be more involved," agrees Vernon Roan, who directs the fuel-cell lab at the University of Florida in Gainesville. His lab is currently testing a small bus that runs entirely on hydrogen fuel cells.

Similar basic issues surround the Hydrogen Fuel Initiative, says Malcolm Weiss, a transportation specialist at the Massachusetts Institute of Technology. Separating hydrogen from sources such as natural gas produces nearly as much greenhouse gas as petroleum fuels, he says, and hydrogen gas cannot be moved through conventional pipelines. That means that it may be necessary to produce hydrogen at the pump, perhaps through electrolysis of water. But the technologies to do this cheaply do not yet exist.

Nevertheless, the congressional committees were generally positive about the hydrogen-car programme - although some members expressed concern that its funding might come at the expense of other research into renewable energy.

Others, such as Senator Byron Dorgan (Democrat, North Dakota), said that the programme needed far more funding to be effective. "It needs to be an Apollo-type programme," Dorgan said, adding that he didn't want to be overly critical of the administration's rare foray into research on new energy sources. "When elephants fly," he said, "you ought not criticize them for being awkward."

"The impression I get from FreedomCAR is that they set objectives but there's no indication of how those objectives will be completed," says Weiss. Nevertheless, Sperling and Roan remain generally positive about the president's proposal. "From a long-term planning perspective it's an undoubtedly good programme," says Roan. 